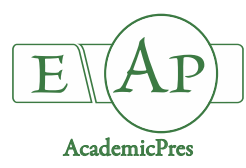

\title{
Activity of the Photosynthetic Apparatus in Phaseolus vulgaris L. Leaves Under the Cadmium Stress
}

\author{
Joanna PUŁA ${ }^{1}$, Beata BARABASZ-KRASNY², Andrzej LEPIARCZYK ${ }^{1}$, \\ Peiman ZANDI ${ }^{3}$, Katarzyna MOŻDŻEN' ${ }^{4 *}$ \\ ${ }^{1}$ University of Agriculture, Faculty of Agriculture and Economics, Al. Mickiewicza 21 Ave, 31-120 Kraków, \\ Poland;rrpula@cyf-kr.edu.pl;a.lepiarczyk@ur.krakow.pl \\ ${ }^{2}$ Pedagogical University of Cracow, Institute of Biology, Department of Botany, Podchorażych 2 St., 30-084 Kraków, \\ Poland; beata.barabasz-krasny@up.krakow.pl \\ ${ }^{3}$ Institute of Environment and Sustainable, Development in Agriculture, Chinese Academy of Agricultural Sciences Beijing 100081, \\ P.R.China; z_rice_b@yahoo.com \\ ${ }^{4}$ Pedagogical University of Cracow, Institute of Biology, Department of Plant Physiology, Podchorażych 2 St., 30-084 Kraków, \\ Poland; katarzyna.mozdzen@up.krakow.pl( ${ }^{*}$ correspondingauthor)
}

\begin{abstract}
The development of civilisation, urbanisation and industrialisation cause to ever increasing contamination of the natural environment. Cadmium belongs to this group of chemical elements, which represent a serious threat, not only for the proper development of plants but also for the health of humans and animals. Hence, the interest of scientists in the toxic effects of this kind chemical elements on the various life functions of organisms. The aim of this study was to investigate the effect of cadmium nitrate aqueous solutions on photosynthetic activity and degree of disorganisation of cell membranes in leaves of common bean (Phaseolus vulgaris L. cv. 'Laurina'). A fully formed second leaves were wetted with cadmium solutions nitrate $\left(\mathrm{Cd}\left(\mathrm{NO}_{3}\right)_{2}\right)$ at concentrations of 5 and $10 \mathrm{mM}$. With the increasing of cadmium concentration and time of its application $(20,40,60 \mathrm{~min}$ and $24 \mathrm{~h})$, the changes in the fluorescence of bean leaves were observed. Under the influence of cadmium ions, damage occurred both on the edge and the central part of the leaves, and then the whole surface. The highest changes of the chlorophyll fluorescence values were observed after $24 \mathrm{~h}$ of application the aqueous cadmium solutions. Use of SPAD chlorophyll Meter, the reduction of chlorophyll content was noticed over time. The flow of electrolytes from the bean leaves was increased with the time and concentration of applied cadmium compounds.
\end{abstract}

Keywords: chlorophyll; common bean; electrolyte leakage; environmental stress; PSII

\section{Introduction}

Heavy metals are polluting of environment and their phytotoxicity affects changes of metabolic processes, anatomy and morphology of plants. In literature are known results of research concerning, among others, accumulation of heavy metals in the soil, in the water, in the transport to the individual organs, and influence on the functioning of the whole plant organism (Aziz et al., 2015). Heavy metals ion uptakes by plants are dependent on many environmental factors. These include soil $\mathrm{pH}$, temperature, oxygen availability, and presence of other chemical elements in the soil (Solymosi and Bert, 2012). Unfortunately, the development of civilisation contributes to the fact that year by year the heavy metals concentration increase in the soil, in the water, also in the air, which are harmful not only to plants but also to all living organisms (Moździerz et al., 2014).

The cadmium is one of the most toxic heavy metal occurs in the environment (Nazar et al., 2012; Clemens et al., 2013). This chemical element is released in the metallurgical industry, waste incineration plants, urban traffic, cement mill, mining, phosphate fertilizers and others (Khan et al., 2015). In atmospheric air, the cadmium is occurred as cadmium oxide ( $\mathrm{CdO}$ ), which is easily soluble in water, which determines its mobility and bioavailability 
406

in the environment (Ostrowska, 2008). Cadmium has similar physical and chemical properties to iron $(\mathrm{Fe})$, copper $(\mathrm{Cu})$ and zinc $(\mathrm{Zn})$ cations. It is bound by the components of cell walls in the root system (Khan et al., 2015). Excessive quantity of cadmium in plants cause, among others, growth of cellular respiration, transpiration and metabolism of nitrogen compounds, enzyme activity, and changes in permeability of cell membranes and DNA structure (Xue et al., 2013).

The response of different plants on stress factors depends on the organism resistance, duration of action and type of stress. The potential of cadmium in phytoremediation of the other heavy metals is underlining in literature. There are a lot of researches on plant growth under conditions of cadmium stress (da Silva et al., 2012; Zhang et al., 2015). In highly industrialised regions, the high cadmium accumulation is noted both roots and leaves vegetables (Czeczot and Skrzycki, 2010). However, the information about effect of cadmium on plant physiology is not fully documented yet and further detailed investigations are needed.

Commonly cultivated in temperate climates, the common bean (Phaseolus vulgaris L.) is a food crop mainly in the form of seeds, which contain large amounts of protein, phytin acid, potassium, phosphorus, and iron compounds. It has a diuretic effect, lowers blood sugar and cholesterol, inhibits the development of colon cancer and has antioxidant properties. Therefore, in a many variants it is a very valuable useful plant. Depending on the variety, it is characterised by different resistance to diseases and pests, but generally quite easy to cultivation (Szafirowska and Kaniszewski, 2014).

The aim of the study was to early monitoring the physiological state of common bean leaves (Phaseolus vulgaris L.), which were wetted of cadmium nitrate solution $\left(\mathrm{Cd}\left(\mathrm{NO}_{3}\right)_{2}\right)$ at 5 and $10 \mathrm{mM}$ concentrations. It was realised on base of measurement of the chlorophyll $a$ fluorescence parameters, chlorophyll content and term the level of disorganisation of cell membranes by determined of the electrolyte leakage.

\section{Materials and Methods}

\section{Plant material}

After $72 \mathrm{~h}$ germinated on distilled water common bean (Phaseolus vulgaris L. cv. 'Laurina') seeds were planted in pots with rinsed river sand. The seedlings thus obtained were grown under greenhouse conditions for 30 days. Once a week they were watered with Steiner's standard medium and every other day with distilled water. The aqueous solutions of cadmium nitrate $\left(\mathrm{Cd}\left(\mathrm{NO}_{3}\right)_{2}\right)$ (Chempur, Poland) were prepared in two molar concentrations of 5 and $10 \mathrm{mM}$. The control group was leaves of plants, were leaves of plants watered with distilled water and Steiner's medium, and untreated of cadmium impact.

\section{Measurement of chlorophyll a fluorescence, chlorophyll}

Chlorophyll fluorescence measurements were performed on 10 different, fully developed second from the top, bean leaves. During the study, the upper surfaces of leaf bean were wetted with aqueous solutions of 5 and $10 \mathrm{mM}$ cadmium nitrate and immediately analysed. Leaves of bean wetted in a suitable cadmium nitrate solutions were decomposed on the filter paper with distilled water and adapted in the dark by $20 \mathrm{~min}$ in a closed FluorCam FC 800C (Photon Systems Instruments, Czech Republic). According to method used by Synowiec et al. (2015), on the same leaf 4 measurements were made: $20 \mathrm{~min}$ after application of the cadmium solutions, after $40 \mathrm{~min}$, followed after $60 \mathrm{~min}$ and $24 \mathrm{~h}$. Among the results obtained, the following parameters were analysed: the zero fluorescence $\left(F_{0}\right)$, the maximum fluorescence $\left(F_{m}\right)$, the stationary fluorescence $\left(\mathrm{F}_{\mathrm{t}}\right)$, the maximum efficiency of the photochemical PSII $\left(\mathrm{F}_{\mathrm{v}} / \mathrm{F}_{\mathrm{m}}\right)$, the non-photochemical quenching (NPQ) and the vitality of PSII (Rfd). The chlorophyll content was measured after 20, 40, 60 min and $24 \mathrm{~h}$ with the use of SPAD-502 Plus chlorophyll Meter (Konica Minolta, Japan).

\section{Electrolyte leakage}

Leaf samples, placed in vials containing $10 \mathrm{ml}$ of deionised water, were incubated on a shaker for $3 \mathrm{~h}$ at $25^{\circ} \mathrm{C}$ to determine the initial electrolyte conductivity (E1). Then they were frozen at $-80{ }^{\circ} \mathrm{C}$. After thawing, the samples were shaken for $3 \mathrm{~h}$ to measure the final conductivity (E2). The percentage of electrolyte leakage (EL) was calculated according to the formula: $\mathrm{EL}=(\mathrm{E} 1 / \mathrm{E} 2) \times 100$.

\section{Statistical analysis}

In results include the arithmetic average of five independent replicates $(n=5)$ for each cadmium solution concentration and control group (distilled water). Besides average values, the standard deviations $( \pm S D)$ were also given. Statistical analysis was performed using nonparametric Kruskal-Wallis test after the Levene's test of variance homogeneity, wherein $\alpha=0.05$. The software Statistica 10.0 for Windows was applied to perform calculations.

\section{Results and Discussion}

Heavy metals cause changes in the metabolic processes of plants, inducing a number of different biochemical processes in the cells. They affect changes in cytoplasm $\mathrm{pH}$, electrostatic potential of cell membranes and ion flow. They contribute to changes in metabolic and transport processes leading to the loss of cellular homeostasis and even to the death of plants (Oves et al., 2016). Cadmium, through high mobility, changes the physiology and morphology of the aboveground organs of plants (Chen et al., 2011). High concentration of cadmium inhibits the access of iron, manganese and zinc, which function as enzyme cofactors, pigments and as structural members of the photosynthetic apparatus (Ahammed et al., 2012). This chemical element affects the amount of electrons in the active centre of the photosynthesis reaction. It inhibits the transport of electrons in the photosynthetic reaction chain by changing the conditions of absorption, conversion and dissipation of heat energy. It leads to the formation of excessive reactive forms of oxygen, affects the function and biological activity of macromolecules, among others proteins and nucleic acids (Emamverdian et al., 2015; Oves et al., 2016). Symptoms of 
toxic cadmium include: chlorotic (yellow) and necrotic (brown) spots, reddening of the veins, twists and necrosis on the leaves (Czeczot and Skrzycki, 2010; Xue et al., 2013).

In recent years, an instrument useful for early monitoring of plant metabolism changes is FluorCam. This fluorimeter allows to accurately characterise the optically invisible changes that occur in the photosynthetic apparatus. Chlorophyll fluorescence is a factor that characterises the photosynthetic activity of plants. Reflects the basic reactions of light energy absorption, as a result of stress factors effect on plants. It illustrates the relationship between photosynthesis and the environment (Baker and Rosenqvist, 2004).

In the experiment, when the cadmium nitrate concentration increased and its application time, changes in bean leaves fluorescence were observed (Figs. 1-3). Under the influence of cadmium ions, damage occurred both on the periphery and the central part of the leaves, and then on the whole of their surface. Probably, changes in the values of the fluorescence parameters were caused by disorganisation and PSII damage (Baszyński, 2014). Along with the time of cadmium exposure, the zero fluorescence $\left(F_{0}\right)$ values increased on the surface of the whole leaf bean regardless of the cadmium solution concentration (Fig. 1). After 20 and $40 \mathrm{~min}$ of application the highest values of $\mathrm{F}_{0}$ were recorded and after $24 \mathrm{~h}$ those values, mainly at the edge of the leaves were reduced. The high values of this parameter are indicative of a lower energy transfer capacity between pigment molecules to the active PSII centre. They indicate on damage of thylakoids and the dissociation of LHCII, which in leads to PSII inactivation (Hansi et al., 2015).

Compared to the control, after $40 \mathrm{~min}$ of application, the maximum fluorescence $\left(\mathrm{F}_{\mathrm{m}}\right)$ values were higher at $5 \mathrm{mM}$ concentration of cadmium nitrate on all surface of the bean leaves. With the increase in cadmium solution application time - after $60 \mathrm{~min}$ and after $24 \mathrm{~h}$, a decrease in the value of this parameter was observed. For $10 \mathrm{mM}$ cadmium nitrate concentration, $\mathrm{F}_{\mathrm{m}}$ values were higher after $20 \mathrm{~min}$ of application, compared to the control. At subsequent of time intervals, after 40 and $60 \mathrm{~min}$ and after $24 \mathrm{~h}$, values of $\mathrm{F}_{\mathrm{m}}$ were decreased, especially in innervation of leaves (Fig. 1). Changes in the values of this parameter indicate that not all electron acceptors in PSII are completely reduced, which signals the stress response in the photosynthetic apparatus. Maximum fluorescence yields at high values are quickly lowered to stationary fluorescence $\left(\mathrm{F}_{\mathrm{t}}\right)$ values that are close to zero fluorescence $\left(\mathrm{F}_{0}\right)$.

The $\mathrm{F}_{\mathrm{t}}$ values depend on the physiological state of the plant and the efficiency of its photosynthesis ( $\mathrm{Li}$ et al., 2015). In conducted studies, only after $20 \mathrm{~min}$ an increase of $F_{t}$ values were observed, and along with the prolonged application time of cadmium compounds in bean leaves decrease of values of this parameter was noticed (Fig. 2).

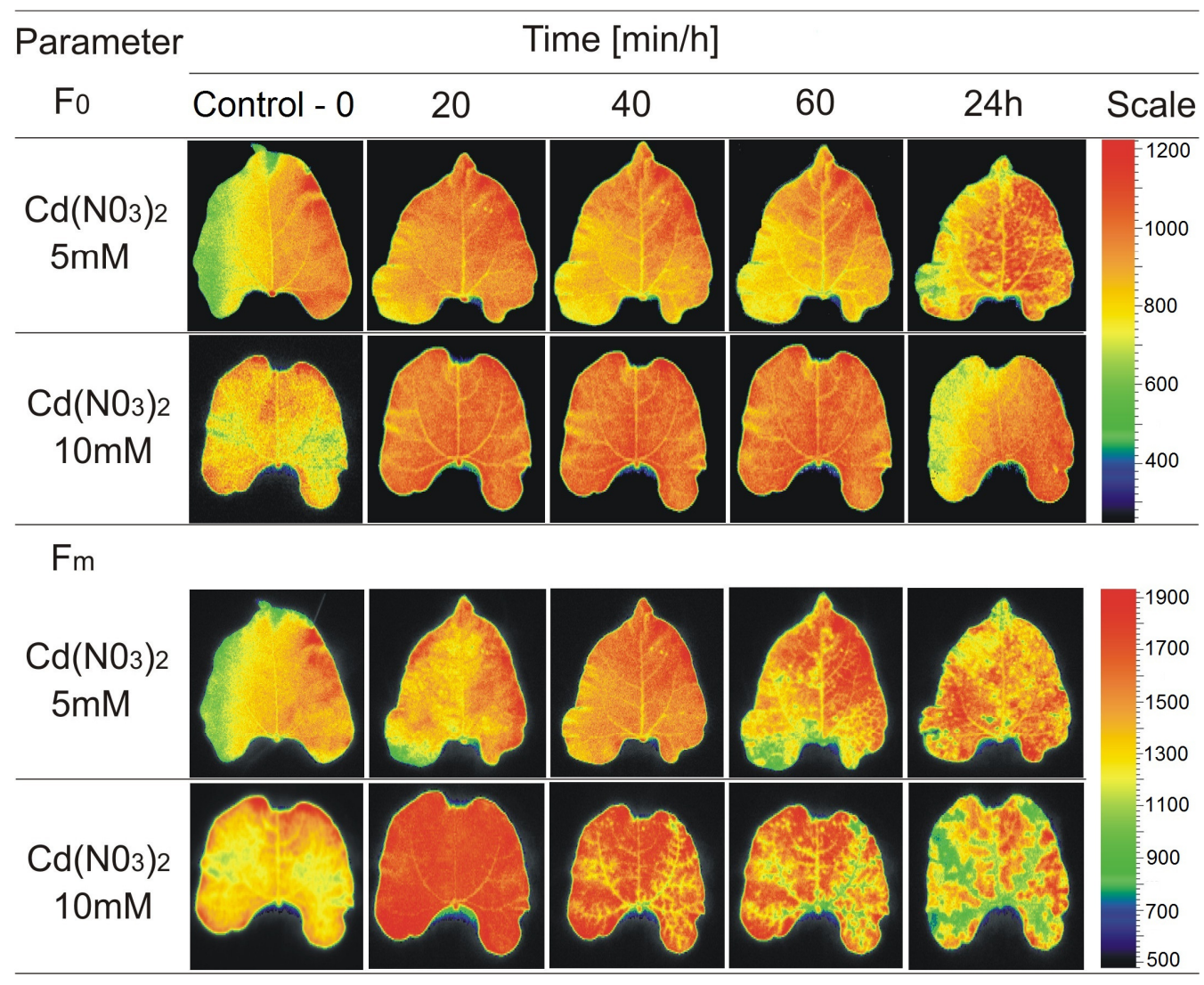

Fig. 1. Imaging chlorophyll a fluorescence in the common bean (Phaseolus vulgaris L.) leaves in cadmium nitrate stress; $\mathrm{F}_{0}-$ the zero fluorescence, $\mathrm{F}_{\mathrm{m}}$ - the maximum fluorescence 


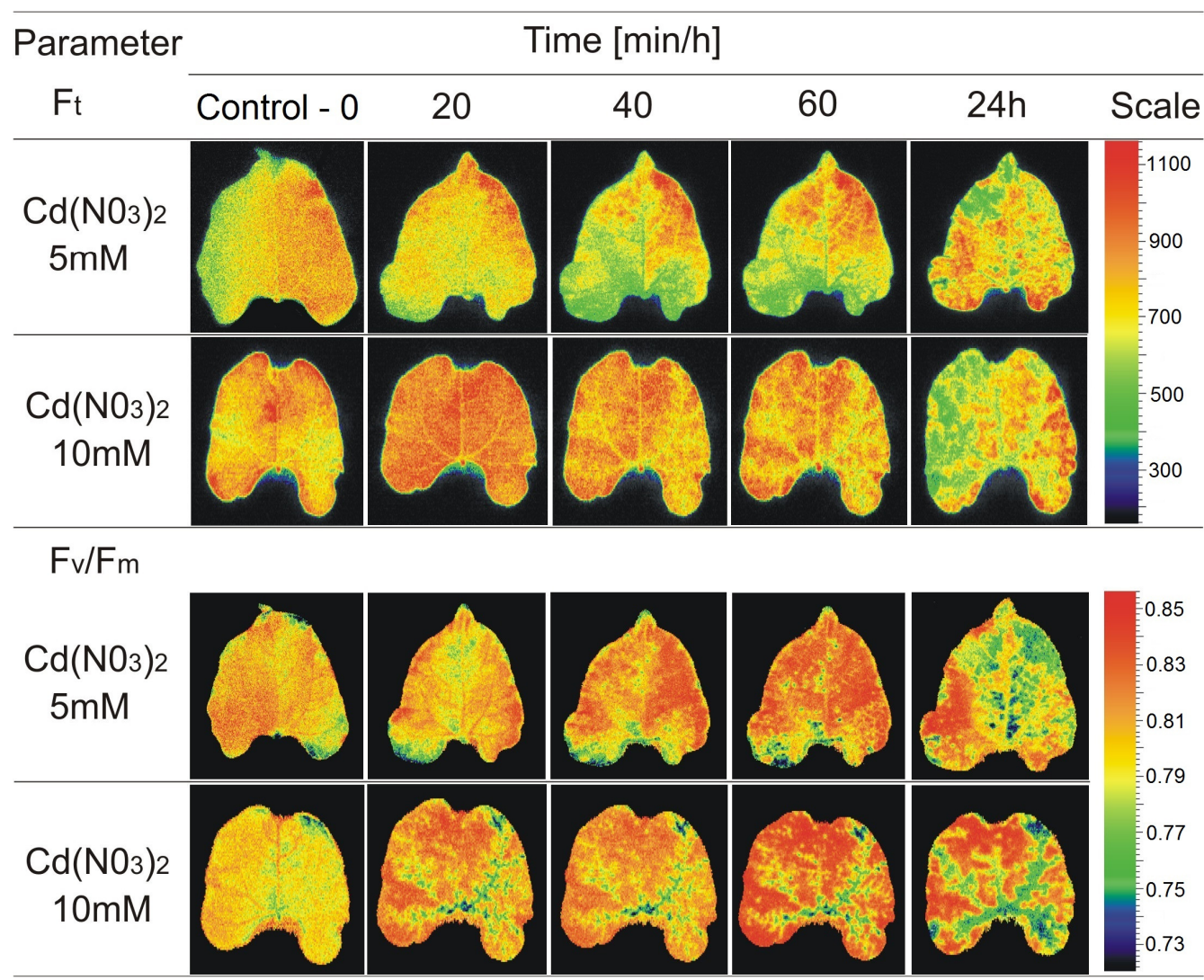

Fig. 2. Imaging chlorophyll $a$ fluorescence in the common bean (Phaseolus vulgaris L.) leaves in cadmium nitrate stress; $\mathrm{F}_{\mathrm{t}}-$ the stationary fluorescence, $\mathrm{F}_{\mathrm{v}} / \mathrm{F}_{\mathrm{m}}$ - the maximum efficiency of the photochemical PSII

After $20 \mathrm{~min}$ of $5 \mathrm{mM}$ cadmium nitrate application, the $\mathrm{F}_{\mathrm{v}} / \mathrm{F}_{\mathrm{m}}$ parameter was significantly lower than the control group. With the extension of application time - after 40 min and $60 \mathrm{~min}$, its value was increased on the surface of the whole bean leaves. However, after $24 \mathrm{~h}$ the value of this parameter was significantly lower, compared to the control sample.

In the case of $10 \mathrm{mM}$ cadmium nitrate concentration, along with the extension of the application time, $\mathrm{F}_{\mathrm{v}} / \mathrm{F}_{\mathrm{m}}$ reduction at the leaves innervation sites was observed, while on the remaining leaf surface the value of this parameter was higher than that of the control leaves (Fig. 2). The $\mathrm{F}_{\mathrm{v}} / \mathrm{F}_{\mathrm{m}}$ parameter as a measure of plant vitality indicates the functioning of PSII. Changes in $\mathrm{F}_{\mathrm{v}} / \mathrm{F}_{\mathrm{m}}$ values may be result of the substitution of cadmium $\left(\mathrm{Cd}^{2+}\right)$ for calcium $\left(\mathrm{Ca}^{2+}\right)$ in the PSII catalytic centre during photoactivation. As a result of the activity of cadmium, can decrease of the ability of electron transport in PSII, it may increase of fluidity thylakoid membranes, cause damage of proteins, which are manifested of photochemical disturbances activity of the photosynthetic apparatus (Solymosi and Bert, 2012; Dezhban et al., 2015).

Non-photochemical quenching (NPQ) is associated with energy losses, which may be caused by $\mathrm{F}_{\mathrm{v}} / \mathrm{F}_{\mathrm{m}}$ changes (Baker, 2008; Sofo et al., 2009). In the case of NPQ parameter, up to $60 \mathrm{~min}$ of cadmium compounds application, regardless of their concentration, values of this parameter decreased, generally on the whole surface of leaves. After $24 \mathrm{~h}$, a high "pointwise" NPQ values were observed on the surface of bean leaves (Fig. 3). Plants under stress conditions can dissipate a lot of their thermal energy with using the xanthophyll cycle (Jahns and Holzwarth, 2012). With longer application of cadmium compounds, the vitality of PSII (Rfd) values decreased on the bean leaves surface. After $24 \mathrm{~h}$ application of $10 \mathrm{mM}$ cadmium nitrate the lowest values were recorded (Fig. 3). Such reactions indicate photochemical disturbances in chloroplast thylakoids. In a stroma of cell, they indicate of disorganisation of the course of enzymatic reactions and changes of the assimilation process of carbon dioxide (Solymosi and Bert, 2012).

Toxic effects of cadmium ions induce a progressive reduction in the amount of chlorophyll (Qiu et al., 2013). In the experiment with bean, along with the passage of time the reduction of chlorophyll content was observed. After 24 $h$ application of cadmium nitrate solutions the highest changes were demonstrated (Fig. 4). In chloroplasts, chlorophyll is stable in compounds, among other with specific proteins, phospholipids and sulpholipids. Disturbance of these relationships accelerates the conversion of chlorophyll and causes loss of green colour (Hu et al., 2014). Cadmium replacing magnesium in the chlorophyll leads to its destruction (Chou et al., 2011). According to Emamverdian et al. (2015) the sensitivity of cadmium increases with age of plants, and it is easier for younger plants to adapting on cadmium stress. 


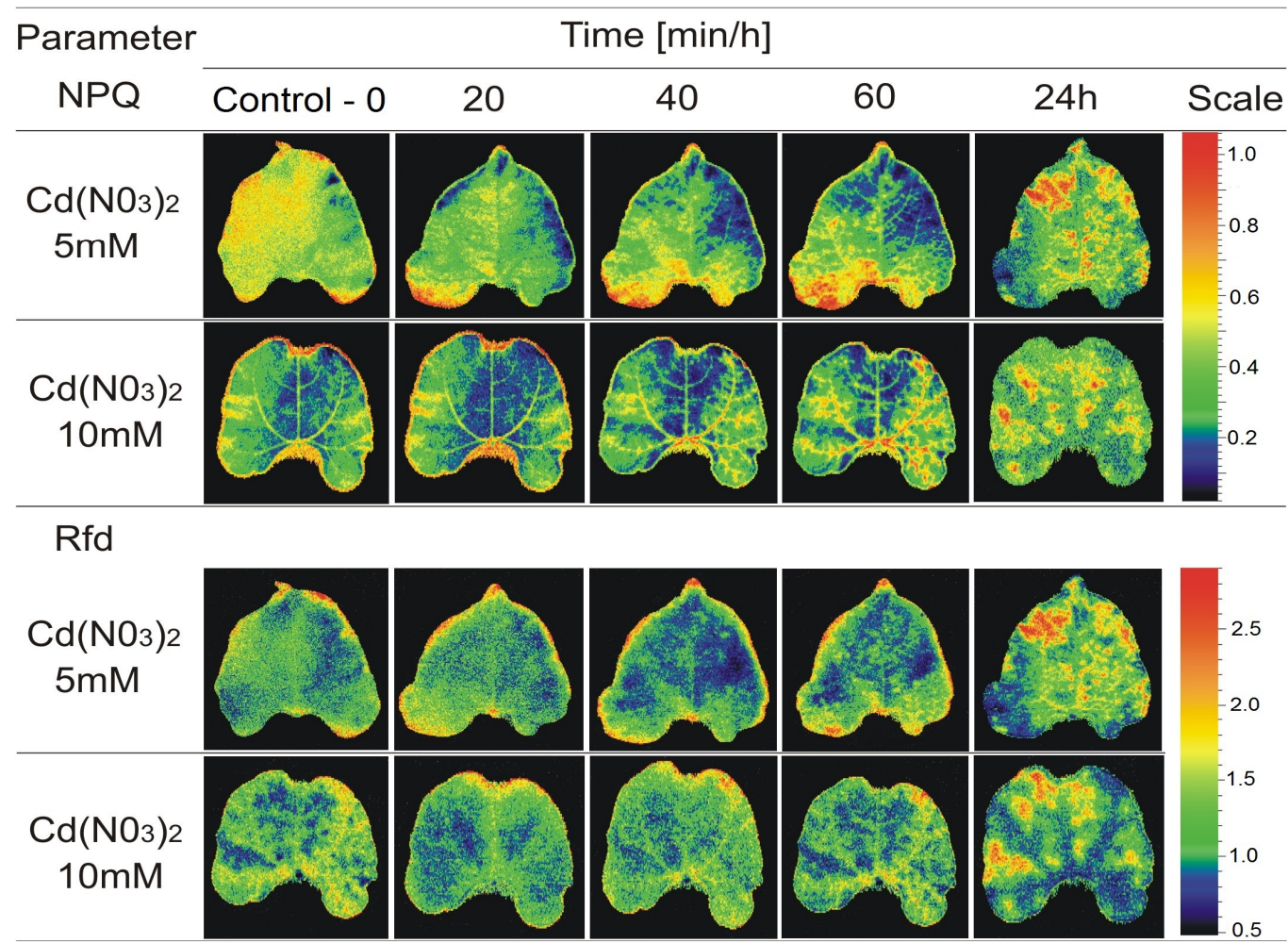

Fig. 3. Imaging chlorophyll $a$ fluorescence in the common bean (Phaseolus vulgaris L.) leaves in cadmium nitrate stress; NPQ the non-photochemical quenching, Rfd - the vitality of PSII

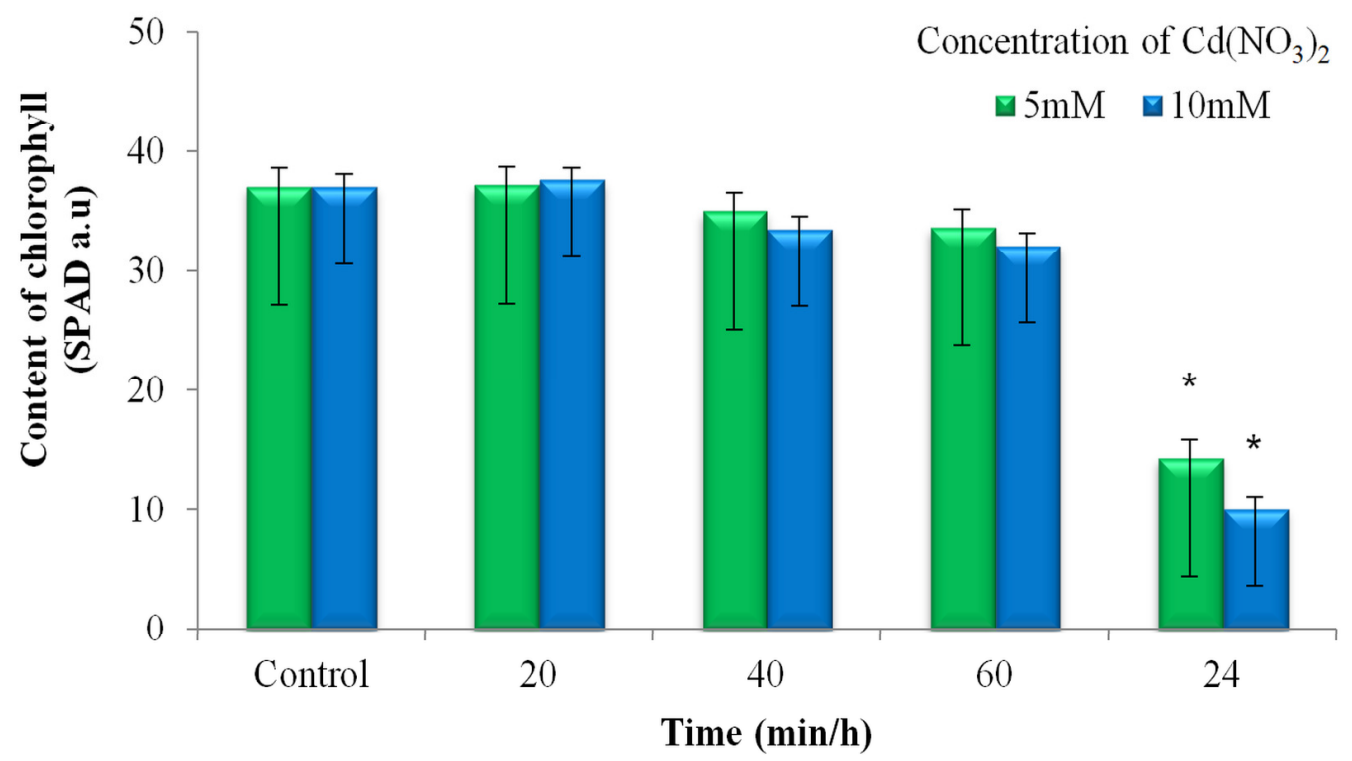

Fig. 4. Chlorophyll content in common bean (Phaseolus vulgaris L.) leaves in cadmium nitrate of 5 and $10 \mathrm{mM}$ concentration after time applications: 20, 40, 60 min and 24 h and control group; means \pm SD $(n=5)$ with * differ significance with KruskalWallis test at $p<0.05$

Changes in photosynthetic activity are due to many other metabolic disturbances that occur in plants under stressful conditions. One of them is disturbance of water management. Cadmium disrupts of water relations in plants by negatively affecting water transport (De Maria et al., 2013; Metwali et al., 2013). It leads to the production of free radicals that contribute to the breakdown of ion channels in cell membranes (Ahmad et al., 2011; Anjum et al., 2015). In studies with bean leaves, compared to the control group the electrolyte leakages were increased with the time of application of cadmium solutions (Fig. 5). 
410

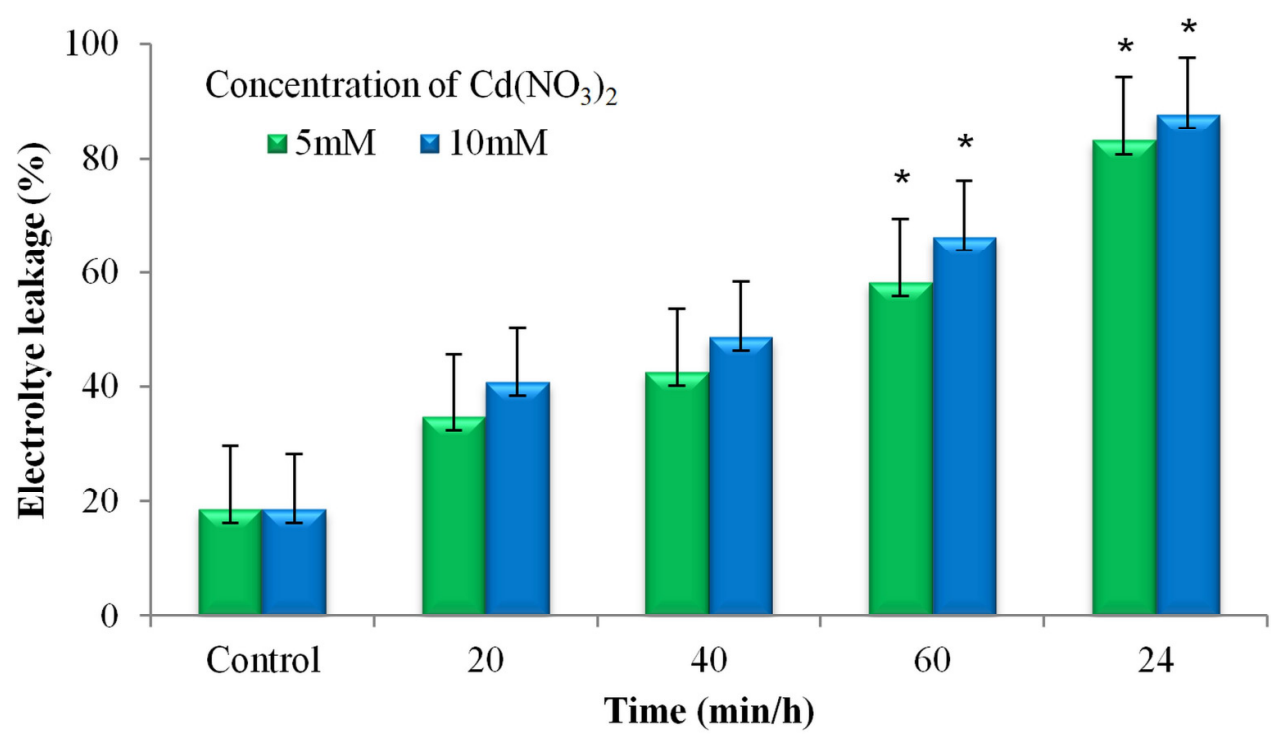

Fig. 5. Electrolyte leakage (\%) from common bean (Phaseolus vulgaris L.) leaves in cadmium nitrate of 5 and $10 \mathrm{mM}$ concentration after time applications: $20,40,60 \mathrm{~min}$ and $24 \mathrm{~h}$ and control group; means \pm SD $(\mathrm{n}=5)$ with * differ significance with Kruskal-Wallis test at $p<0.05$

Probably, these changes are due to the different concentration and time of the cadmium compounds application. Also they depend on the species and variety, the part of plant and the stage of development. However, regardless of age, the plants have some protection against the negative effects of cadmium and other heavy metals. The activity of antioxidant enzymes and the ability to synthesize cadmium binding proteins are one of many defence mechanisms activated in response to high concentrations of cadmium (Czeczot and Skrzycki, 2010; Anjum et al., 2015). This kind of defence for plant organisms is not enough. Therefore, in order to prevent the destructive effect of heavy metals, their content must already be controlled in the structures of plant propagation, e.g., in seeds, tubers and roots. The use of cadmium and other heavy metals in industry should be to eliminate by modifying production processes. It is necessary to regulate and coordinate the production of organic compounds, water and ion collection and their distribution.

\section{Conclusions}

Under the influence of cadmium ions, at first the damage to either the edge, at the second the central part of the leaves of beans, and then the whole surface were occurred. Along with the prolongation of time exposure to cadmium, the zero fluorescence $\left(\mathrm{F}_{0}\right)$ values were increased on the surface of the whole leaves of bean, regardless of the concentration of the solution. Compared to control, after 40 min of application of $5 \mathrm{mM}$ cadmium nitrate and already after $20 \mathrm{~min}$ of application of $10 \mathrm{mM}$ concentration this compound, the maximum fluorescence $\left(\mathrm{F}_{\mathrm{m}}\right)$ values were higher on the whole leaves surface of bean. After $20 \mathrm{~min}$ of application of $5 \mathrm{mM}$ cadmium nitrate, the $\mathrm{F}_{\mathrm{v}} / \mathrm{F}_{\mathrm{m}}$ parameter significantly decreased compared to the control; extension of the application time ( 40 and $60 \mathrm{~min}$ ), caused these values increased. After $60 \mathrm{~min}$, regardless of their concentration, the non-phytochemical quenching values (NPQ) were decreased, generally on the surface of the whole leaves. The value of the PSII vitality (Rfd) decreased with the extension of the cadmium compounds application time. Along with the prolongation of time cadmium application, the reduction of chlorophyll content and the increase of electrolyte leakage from cell membranes were observed; after $24 \mathrm{~h}$, the highest changes of chlorophyll were demonstrated.

\section{References}

Ahammed GJ, Choudhary SP, Chen S, Xia X, Shi K, Zhou Y, Yu Y (2013). Role of brassinosteroids in alleviation of phenanthrene cadmium cocontamination induced photosynthetic inhibition and oxidative stress in tomato.Journal of Experimental Botany 64(1):199-213.

Ahmad P, Nabi G, Ashraf M (2011). Cadmium-induced oxidative damage in mustard (Brassica juncea (L.) Czern. and Coss.) plants can be alleviated by salicylic acid. South African Journal of Botany 77:3644.

Anjum SA, Tanvee M, Hussain S, Bao M, Wang L, Khan I, Ullah E, Tung SA, Samad RA, Shahzad B (2015). Cadmium toxicity in maize (Zea mays $\mathrm{L}$.): consequences on antioxidative systems, reactive oxygen species and cadmium accumulation. Environmental Science and Pollution Research 22(21):17022-17030.

Aziz T, Ahmad B, Ashraf M, Arifeen MZU, Nawab S, Nabi GA (2015). Mini review on lead $(\mathrm{Pb})$ toxicity in plants. Journal of Biology and Life Science 6(2):91-101.

Baker NR (2008). Chlorophyll fluorescence: a probe of photosynthesis in vivo. Annual Review of Plant Biology 59:89-113.

Baker NR, Rosenqvist E (2004). Applications of chlorophyll fluorescence can improve crop production strategies: an examination of future possibilities.Journal of Experimental Botany 55(403):1607-162.

Baszyński $\mathrm{T}$ (2014). Interference of $\mathrm{Cd}^{2+}$ in functioning of the photosynthetic apparatus of higher plants. Acta Societatis Botanicorum 
Poloniae 55(2):291-304.

Chen X, WangJ, Shi Y,Zhao MQ, Chi GY (2011). Effects of cadmium on growth and photosynthetic activities in pakchoi and mustard. Botanical Studies 52:41-46.

Chou T-S, Chao Y-Y, Huang W-D, Hong C-Y, Kao CH (2011).Effect of magnesium deficiency on antioxidant status and cadmium toxicity in rice seedlings.Journal of Plant Physiology 168(10):1021-1030.

Clemens S, Aarts MGM, Thomine S, Verbruggen N (2013). Plant science: the key to preventing slow cadmium poisoning. Trends in Plant Science 18(2):92-99.

Czeczot H, Skrzycki M (2010). Cadmium - element completely unnecessary for the organism. Advances in Hygiene and Experimental Medicine 64:38-49 [in Polish].

da Silva AJ, do Nascimento CWA, da Silva Gouveia-Neto A, da Silva EA (2012). LED-induced chlorophyll fluorescence spectral analysis for the early detection and monitoring of cadmium toxicity in maize plants. Water, Air, and Soil Pollution 223(6):3527-3533.

De Maria S, Puschenreiter M, Rivelli AR (2013). Cadmium accumulation and physiological response of sunflower plants to $\mathrm{Cd}$ during the vegetative growing cycle. Plant, Soil Environment 59(6):254261.

Dezhban A, Shirvany A, Attarod P, Delshad M, Matinizadeh M, Khoshnevis M (2015). Cadmium and lead effects on chlorophyll fluorescence, chlorophyll pigments and proline of Robinia pseudoacacia. Journal of Forestry Research 26(2):323-329.

Emamverdian A, Ding Y, Mokhberdoran F, Xie Y (2015). Heavy metal stress and some mechanisms of plant defense response. The Scientific World Journal 1-18.

Hansi I, Yaakoubi H, Hamdani S, Tajmir-Riahi H-A, Carpentier R(2015). Mechanism of interaction of $\mathrm{Al}^{3+}$ with the proteins composition of photosystem II. PLoSOne 10(3):e0120876.

$\mathrm{Hu}$ H, Wang L, Wang Q, Jiao L, Hua W, Zhou Q, Huan X (2014). Photosynthesis, chlorophyll fluorescence characteristics, and chlorophyll content of soybean seedlings under combined stress of bisphenol A and cadmium. Environmental Toxicology and Chemistry 33(11):24552462.

Jahns P, Holzwarth JA (2012). The role of the xanthophyll cycle and of lutein in photoprotection of photosystem II. Biochimica et Biophysica Acta(BBA) - Bioenergetics 1817(1):182-193.

Khan A, Khan S, Khan MA, Qamar Z, Waqas M (2015). The uptake and bioaccumulation of heavy metals by food plants, their effects on plants nutrients, and associated health risk: a review. Environmental Science and Pollution Research 22(18):13772-13799.

LiS, Yang W, Yang T, Chen Y, Ni W (2015). Effects of cadmium stress on leaf chlorophyll fluorescence and photosynthesis of Elsholtzia argyi - a cadmium accumulating plant. International Journal of Phytoremediation 17(1-6):85-92.
Metwali MR, Gowayed SMH, Al-Maghrabi OA, Mosleh YY (2013). Evaluation of toxic effect of copper and cadmium on growth, physiological traits and protein profile of wheat (Triticum aestivum $\mathrm{L}$.), maize (Zea mays L.) and sorghum (Sorghum bicolor L.). World Applied Sciences Journal 21(3):301-314.

Moździerz A, Juszko-Piekut M, Stojko J (2014). Cadmium contamination of atmospheric air in the Silesian cities. Environmental Medicine 17(1):25-33 [in Polish].

Nazar R, Iqbal N, Masood A, Khan MIR, Syeed S, Khan NA (2012). Cadmium toxicity in plants and role of mineral nutrients in its alleviation. American Journal of Plant Sciences3(10):1476-1489.

Ostrowska P (2008). Cadmium, occurrence, sources of pollution and recycling methods. Mineral Resources Management 24:255-260 [in Polish].

Oves M, Saghir Khan M, Huda Qari A, Nadeen Felemban M, Almeelbi T (2016). Heavy metals: biological importance and detoxification strategies. Journal of Bioremediation and Biodegradation 7(2):1-15.

Qiu ZY, Wang LH, Zhou Q (2013). Effects of bisphenol A on growth, photosynthesis and chlorophyll fluorescence in above-ground organs of soybean seedlings. Chemosphere 90(3):1274-1280.

Sofo A, Dichio B, Montanaro G, Xiloyannis C (2009). Photosynthetic performance and light response of two olive cultivars under different water and light regimes. Photosynthetica 47(4):602-608.

Solymosi K, Bert M (2012). Soil metals, chloroplasts, and secure crop production: a review. Agronomy for Sustainable Development 32(1):245-272.

Synowiec A, Możdżeń K, Skoczowski A (2015). Early physiological response of broccoli leaf to foliar application of clove oil and its main constituents. Industrial Crops and Products 74:523-529.

Szafirowska A, Kaniszewski S (2014). The instruction of growing common bean (Phaseolus vulgaris L.) on seeds under environmental conditions. Selection of species and varieties of vegetables for organic farming and quality assessment of seed. Instytut Ogrodnictwa Skierniewice Pracownia UprawyiNawożenia Warzyw 1-10 [in Polish].

Xue ZC, Gao HY, Zhang LT (2013). Effects of cadmium on growth, photosynthetic rate and chlorophyll content in leaves of soybean seedlings. Biologia Plantarum 57(3):585-590.

Zhang C, GuoJ, Lee DK, Anderson E, Huang H(2015). Growth responses and accumulation of cadmium in switchgrass (Panicum virgatum $\mathrm{L}$.) and prairie cordgrass (Spartina pectinata Link). Royal Society Chemistry Advances 5(102):83700-83706. 